\title{
NANOCHROMIUM CITRATE: ANTIHYPERGLYCEMIC AND PANCREATOPROTECTIVE ACTION AGAINST UNDERLYING DEXAMETHASONE-INDUCED DIABETES MELLITUS
}

\author{
Kateryna Sadohurska ${ }^{1}$, Rayisa Kosuba ${ }^{2}$, Nataliia Muzyka ${ }^{3}$, Iuliia Greshko ${ }^{4}$, \\ Roksolana Basaraba ${ }^{5}$
}

\begin{abstract}
:
Introduction: The Ukrainian State Scientific-Research Institute of Nanobiotechnology and Resources Saving has received nanochromium citrate (NCC), a new chrome compound, by means of the electric pulse aquananotechnology method.

Objectives: to determine nanochromium citrate efficacy with experimental dexamethasone-induced diabetes through the results of antihyperglycemic activity and its effect on the pancreatic histological structure.

Methods: diabetes mellitus was simulated by dexamethasone administration on 18-month male rats. The morphological structure of the pancreas was examined in comparison with metformin. Examination of the pancreas morphological structure considered the amount, distribution and size of the pancreatic islets and their cellular shape.

Results: on the $14^{\text {th }}$ day of simulated diabetes mellitus the preventitive -therapeutic indication of nanochromium citrate promoted a decrease of glycemia level twice. The administration of nanochromium citrate with underlying diabetes mellitus is not inferior to metformin and its protective effect on the pancreas morphological structure exceeds the effect of metformin.

Conclusion: nanochromium citrate of experimental dexamethasone-induced diabetes mellitus in rats decreases the glycemia level twice which does not differ reliably from the effect of metformin antihyperglycemic. The cytoprotective effect of nanochromium citrate produced on the histological structure of the pancreas is found to exceed metformin action.
\end{abstract}

UDC Classification: 615.252.349.7:616.379, DOI: https://doi.org/10.12955/pmp.v1.102

Keywords: nanochromium citrate, hypoglycemic activity, experimental diabetes mellitus, metformin

\section{Introduction}

The issue of diabetes mellitus (DM) considering its occurrence, severity and complications, is one of the most urgent in the world (Crawford, 2017; Pan'kiv, 2015). The number of DM patients is hypothesized to increase to 642 million by 2040 (Ogurtsova, 2015). In Ukraine, the DM sickness rate increases annually by 5-7\%. Nowadays there are over 2 million people with DM in Ukraine (Tkachenko, 2014; Tsytovs'kyy, 2017). In spite of the introduction of new diagnostic and therapeutic technologies into medical practice, the search for effective and safe medicinal means for DM treatment remains a high priority.

Due to nanotechnology, the contemporary state of scientific development has been supplied by new achievements in the fields of nanobiology, nanomedicine, and nanopharmacology (Chekman, 2017). Nanoparticles and nanostructured materials are already used as new remedies, biosensors and devices for visualization and diagnostics (Holovenko, 2008; Yigit, 2012; Malekzad, 2017). Dynamic research of toxicological and pharmacological properties of nanoparticles of biometals such as silica, silver, iron, copper and their composites, is being conducted in Ukraine (Savchenko, 2014; Doroshenko, 2014; Pryskoka, 2016; Simonov, 2016).

Chromium nanoparticles are considered to be promising structures used in nanomedicine. Scientific literature contains sporadic information concerning the biological activity of chromium nanoparticles (Zha, 2007; Chandra, 2016). Since chromium is an essential trace element entering the body from outside, it participates in the regulation of insulin production and metabolism, provides pancreatic functioning, intensifies insulin action when contained in glucose tolerance factor (GTF) (Jeejeebhoy, 1999), and being a low molecular organic complex, chromium compounds can supplement the current treatment of DM (Suslyk, 2014; Dashkevich, 2013). Dietary supplements containing chromium are

\footnotetext{
${ }^{1}$ Higher State Educational Establishment of Ukraine „Bukovinian State Medical University“, Chernivtsi, Ukraine, sadogurska.katya@ukr.net

${ }^{2}$ Higher State Educational Establishment of Ukraine „Bukovinian State Medical University“, Chernivtsi, Ukraine, gordienko.viktor@bsmu.edu.ua

${ }^{3}$ Higher State Educational Establishment of Ukraine „Bukovinian State Medical University“, Chernivtsi, Ukraine, muzykanataliya@ukr.net

${ }^{4}$ Higher State Educational Establishment of Ukraine „Bukovinian State Medical University“, Chernivtsi, Ukraine,greshkojulia@ukr.net

${ }^{5}$ Higher State Educational Establishment of Ukraine „Bukovinian State Medical University“, Chernivtsi, Ukraine, roksishka@i.ua
} 
recommended for type 2 DM ("Chromium active", "Chromium Chelat", "Solgar Chromium Picolinate", "Insuvit") in order to normalize the metabolism of proteins, fats and carbohydrates (Shcherbak, 2004; Lewicki, 2014).

The Ukrainian State Scientific-Research Institute of Nanobiotechnology and Resources Saving (Ltd "Nanomaterials and Nanotechnology", Kyiv) has received nanochromium citrate (NCC), a new chrome compound, by means of the electric pulse aquananotechnology method (Kosinov, 2008). Our previous screening studies determined hypoglycemic action available in NCC (Sadohurska, 2016). Its pathogenic mechanism requires further study.

Thus, the aim of this study was to determine nanochromium citrate efficacy within experimental dexamethasone-induced diabetes by the results of antihyperglycemic activity and its effect on the pancreatic histological structure.

\section{Material and Methods}

The study was conducted on albino outbred 18-month male rats with a body weight of 220-270 g. Experimental diabetes mellitus (EDM) was simulated by subcutaneous injection of dexamethasone in a dose of $0.125 \mathrm{mg} / \mathrm{kg}$ of the body weight for 14 days (Stefanov, 2001). Metformin Sandoz was used as a drug of comparison in the form of a water suspension. It was introduced into the stomach by means of a probe in a dose of $200 \mathrm{mg} / \mathrm{kg}$ (Poltorak, 2000). Simultaneously with dexamethasone NCC was introduced in the stomach in a dose of $0.01 \mathrm{mg} / \mathrm{kg}$ (Sadohurska, 2016) or metformin. The animals were divided into 4 groups. I - intact rats, II - control pathology, III - dexamethasone + NCC, IV dexamethasone + metformin. Antihyperglycemic properties of NCC were assessed by basal glycemia (in the dynamics on the 1st, 7th, 14th day) by means of a glucometer (Accu-Chek Active New, Germany). To assess morphological changes histological sections of tissues stained with hematoxylin and eosin (Venerucci, 2016) were studied by means of a light microscopy method (microscope "LUMAM-P8", digital camera Olympus C 740UZ). All interventions were conducted in accordance with the criteria outlined in the European Union Directive 2010/63/EU "On the protection of animals used for scientific purposes" (2010).

Statistical analysis of the data was performed using SPSS 17.0 software. All data are represented as a mean \pm standard error of the mean $(\mathrm{M} \pm \mathrm{m})$. Estimation of the differences between the samples was conducted using a parametric Student's t-test and nonparametric Mann-Whitney U test. The values $\mathrm{p}<0.05$ were considered significant.

\section{Results and Discussion}

In the first day glucose concentration in the blood of intact and experimental animals ranged within the norm and did not differ among animals from the other groups (Table 1). On the 7th day of modeling control pathology, the glucose concentration in the blood of animals after dexamethasone administration increased by 1.3 times. Similar glycemia increase was observed among animals from groups III and IV. On the 14th day dexamethasone-induced glycemia increased practically twice as much, and the glucose level in the blood increased 2.6 times in comparison to the intact control, which is a reliable sign of experimental type 2 DM reproduction (Poltorak, 2000). The glycemia level in animals receiving NCC as a preventive-therapeutic measure remained on the initial level on the 14th day (similar to that of the 7th day), though it appeared to be 2.1 times lower than that of the animals with EDM. A similar effect was observed when metformin was introduced (Table 1), which is indicative of hypoglycemic action of NCC similar to that of the reference-drug metformin. Literary data indicate that correction hypoglycemic effect of NCC is likely to occur in case of streptozotocininduced DM as well (Iskra, 2014), and when chromium citrate is administered for alloxan-induced $\mathrm{DM}(\mathrm{Li}, 2011)$.

Since the major insulin producer in the body is beta-cells of islets of Langerhans, the effect of NCC on the morphological structure of the pancreas with underlying EDM was examined. The islets of Langerhans in intact animals were found to occur practically in every visual field (99\%). Their size was on an average $205.0 \pm 12.65 \mathrm{mcm}$, the cellular profile on one histological section of the islet was $84.0 \pm 5.69$ (Fig. 1).

In animals with EDM, the general amount of the islets is considerably smaller (under $27 \%$ in the visual field). Their size is 4.8 times smaller (up to $43.0 \pm 4.27 \mathrm{mcm}$ ), and their shape is changed to an 


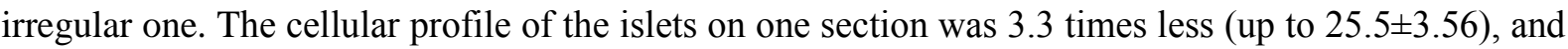
the majority of cells were found to be in the state of necrosis (Fig. 2).

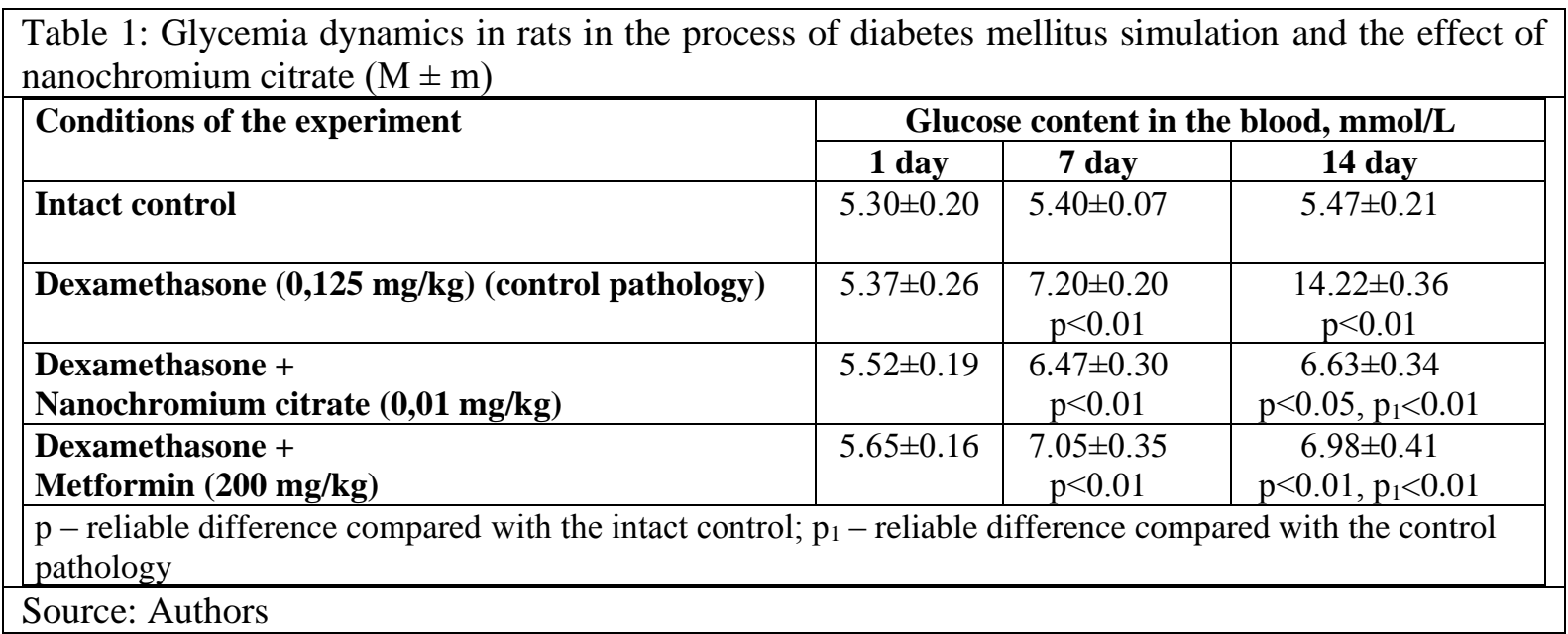

\begin{tabular}{|l|l|}
\hline $\begin{array}{l}\text { Figure 1: Slide mount of the pancreatic islet of } \\
\text { an intact rat. 1 - islet of Langerhans. H\&E. } \\
\text { x100. }\end{array}$ & $\begin{array}{l}\text { Figure 2: Slide mount of the pancreatic islet with } \\
\text { experimental diabetes mellitus. 1 - islet of } \\
\text { Langerhans. H\&E. x100. }\end{array}$ \\
\hline & (1)
\end{tabular}

It should be noted that in comparison with EDM animals, the administration of NCC promoted considerably decreased alternative signs in the endocrine part of the gland (Fig. 3). Though the size of the islets did not differ considerably from that of the intact animals $(217.5 \pm 19.36 \mathrm{mcm})$, their cellular profile appeared to be 5 times larger than with EDM, and it even increased the profile of the intact rats (133.0 \pm 12.4 against $84 \pm 5.69$ in the control). Reduced degenerative changes in the morphological structure of the gland in the process of EDM simulation and NCC effect are evidenced by the fact that only single cells of the islets were in the state of necrosis. Thus, in the process of EDM simulation NCC decreases the toxic effect of dexamethasone on the morphological structure of the gland.

The size of the islets of Langerhans in animals receiving metformin (Fig. 4) ranged within $140.0 \pm 11.1 \mathrm{mcm}$ and they were 1.5 times smaller than when NCC was administered under similar conditions. Though the cellular profile on one histological section of the islet (67.5 \pm 4.98$)$ was close to the level of intact animals, it appeared to be two times smaller than that of the cellular profile under conditions of NCC action. Necrotic signs were found in 3-12\% of cells.

Therefore, pathomorphologic studies of the pancreas of rats with EDM are indicative of a more marked protective effect of NCC by morphometric parameters in comparison with metformin action (Table 2). 


\begin{tabular}{|l|l|}
\hline $\begin{array}{l}\text { Figure 3: Slide mount of the pancreatic islet } \\
\text { under nanochromium citrate action with } \\
\text { underlying experimental diabetes mellitus. 1 - } \\
\text { islet of Langerhans, 2 - group of necrotized } \\
\text { cells. H\&E. x100. }\end{array}$ & $\begin{array}{l}\text { Figure 4: Slide mount of the pancreatic islet } \\
\text { under metformin action with underlying } \\
\text { experimental diabetes mellitus. 1 - islet of } \\
\text { Langerhans, 2 - group of necrotized cells. H\&E. } \\
\text { x100. }\end{array}$ \\
\hline &
\end{tabular} \mid

Table 2: Morphometric parameters of the pancreatic islets under conditions of nanochromium citrate and metformin action with underlying experimental DM $(\mathrm{M} \pm \mathrm{m})$

\begin{tabular}{|l|c|c|c|}
\hline $\begin{array}{l}\text { Conditions of the } \\
\text { experiment }\end{array}$ & $\begin{array}{c}\text { Size of the islets of } \\
\text { Langerhans, mcm }\end{array}$ & Cellular profile & Terms of the experiment \\
\hline Intact control & $205.00 \pm 12.65$ & $84.0 \pm 5.69$ & lacking \\
\hline $\begin{array}{l}\text { Control } \\
\text { pathology } \\
(\mathbf{E D M})\end{array}$ & $43.00 \pm 4.27^{*}$ & $25.5 \pm 3.56^{*}$ & single cells \\
\hline EDM+NCC & $217.5 \pm 19.36 \#$ & $133.0 \pm 12.4 \#$ & single cells \\
\hline EDM+metformin & $140.00 \pm 11.1 \#$ & $67.5 \pm 4.98 \#$ & \\
\hline $\begin{array}{l}*-\text { reliable difference compared with the intact control }(\mathrm{p}<0.05), \#-\text { reliable difference compared with the } \\
\text { control pathology (p<0.05) }\end{array}$ \\
\hline Source: Authors
\end{tabular}

\section{Conclusion}

Thus, NCC administration with underlying EDM decreases glucose concentration in the blood twice as much, which does not differ reliably from the antihyperglycemic effect of metformin. The cytoprotective effect of NCC produced on the histological structure of the pancreas is found to exceed the metformin action (1.5 times larger size and twice as much cellular profile of the pancreatic islets of Langerhans).

\section{References}

Borysevych, V. B., Kaplunenko, V. H., Kosinov M. V. (2010). Nanomaterialy v biolohiyi. Osnovy nonoveterynariyi [Nanomaterials in Biology. Basics of non-veterinary medicine]. K: Avitsena.

Chandra, S., Kumar, A. (2016). Spectral, thermal and morphological studies of chromium nanoparticles. Spectrochimica acta. Part A., Molecular and biomolecular Spectroscopy, 102, 250-255. https://doi.org/10.1016/j.saa.2012.10.003

Chekman, I. S. (2017). Nanonauka: medyko-biolohichni osnovy [Nanoscience: Biomedical Basics]. Kyiv, Vydavnychyy dim Medknyha.

Crawford, K. (2017). Review of 2017 diabetes standards of care. Nurs. Clin. North Am, 52 (4), 621-663. https://doi.org/10.1016/j.cnur.2017.07.010

Dashkevich, O. V. et al. (2013). Klinicheskaya otsenka effektivnosti diyeticheskoy korrektsii metabolicheskogo sindroma s ispol'zovaniyem spetsializirovannogo pishchevogo produkta, obogashchennogo khromom [Clinical evaluation of the 
effectiveness of dietary correction of metabolic syndrome using a specialized food product enriched in chromium]. Vopr. pitaniya, 3, 30-36.

Doroshenko, A. M. et al. (2014). Protyanemichna aktyvnist' substantsiyi nanochastynok zaliza za umov peroral'noho vvedennya shchuram [Anti-anemic activity of the substance of iron nanoparticles under oral administration to rats]. Farmakolohiya ta likars'ka toksykolohiya, 3 (39), 12-19.

Holovenko, M., Larionov, V. (2008). Adresna dostavka nanosystemamy likars'kykh zasobiv do holovnoho mozku [Targeted delivery by nanosystems of drugs to the brain]. Visnyk farmakolohiyi ta farmatsiyi, 4, 8-16.

Iskra, Ya., Slivins'ka, O. M. (2014). Vplyv tsytratu khromu na vuhlevodnyy obmin u krovi shchuriv za streptozototsyn indukovanoho diabetu [Effect of chromium citrate on carbohydrate metabolism in rat blood for streptozotocin-induced diabetes]. Medychna khimiya, 16, 3 (60). 16-19.

Jeejeebhoy, K. N. (1999). Chromium and parenteral nutrition. Trace Elements in Experimental Medicine, 12, 2, 85-89. https://doi.org/10.1002/(SICI)1520-670X(1999)12:2<85::AID-JTRA5>3.0.CO;2-Z

Kosinov, M. V., Kaplunenko, V. H. (2008). Sposib otrymannya akvakhelativ nanometaliv «Eroziyno-vybukhova nanotekhnolohiya otrymannya akvakhelativ nanometaliv» [Method of obtaining nanometals aqua chelates "Erosion-explosive nanotechnology of obtaining nanometals aqua chelates"] (Ukraine Patent identifier № 29856).

Lewicki, S.et al. (2014). The role of Chromium III in the organism and its possible use in diabetes and obesity treatment. Ann. Agric. Environ. Med, 21, 2, 331-335. https://doi.org/10.5604/1232-1966.1108599

Li, F. et al. (2011). Anti-diabetic properties of chromium citrate complex in alloxan-iduced diabetic rats. Journal of Trace Elements in Medicine and Biology, 25, 4, 218-224. https://doi.org/10.1016/j.jtemb.2011.08.143

Malekzad, H. et al. (2017). Noble metal nanoparticles in biosensors: recent studies and applications. Nanotechnol. Rev, 6, 3 , 301-329. https://doi.org/10.1515/ntrev-2016-0014

Ogurtsova, K. et al. (2015). IDF Diabetes Atlas: Global estimates for the prevalence of diabetes for 2015 and 2040. Diabetes Res. Clin. Pract, 128, 40-50. https://doi.org/10.1016/j.diabres.2017.03.024

Pankiv, V. I. (2015) Suchasni pidkhody do medykamentoznoyi profilaktyky tsukrovoho diabetu 2-ho typu. [Current approaches to the medical prevention of type 2 diabetes.]. Klinichna endokrynolohiya ta endokrynna khirurhiya, 2 (50), 5863.

Poltorak, V. V. (2000). Vplyv metforminu na rozvytok insulinorezystentnosti, indukovanoyi deksametazonom u shchuriv. Endokrynolohiya [Effect of metformin on the development of dexamethasone-induced insulin resistance in rats. Endocrinology.]. T. 5, 2, 249-251.

Pryskoka, A. O. (2016). Eksperymental'ne obgruntuvannya farmakolohichnykh vlastyvostey nanochastynok sribla [Experimental substantiation of pharmacological properties of silver nanoparticles], Kharkiv: NFaU, 22.

Sadohurska, K. V. (2016). Do pytannya bezpechnosti nanokhromu tsytratu za umov povtornoho vvedennya [To the question of the safety of nanochrome citrate under the conditions of re-introduction]. Farmakolohiya ta likars'ka toksykolohiya, 4-5 (50), 95-100.

Savchenko, D. (2014). Eksperymental'ne obgruntuvannya protymikrobnoyi ta sorbtsiynoyi aktyvnosti enterosorbentu z nanosriblom [Experimental substantiation of antimicrobial and sorption activity of enterosorbent with nanosilver]. NFaU. Kharkiv.

Shcherbak, O. et al. (2004). Vykorystannya kompleksnykh likars'kykh zasobiv z vmistom mikroelementiv u likuvanni khvorykh na tsukrovyy diabet [The use of complex drugs containing trace elements in the treatment of patients with diabetes]. Farmatsevtychnyy zhurnal, 1, 101-104.

Simonov, P. V. (2016). Eksperymental'ne doslidzhennya farmakolohichnykh vlastyvostey nanochastynok midi ta yikh kon"yuhatu z tseftriaksonom [Experimental study of the pharmacological properties of copper nanoparticles and their conjugates with ceftriaxone], Kharkiv: NFaU.

Stefanov, O. V. et al. (2001). Doklinichni doslidzhennya likars'kykh zasobiv [Preclinical studies of medicines]. Kyiv: Avitsena.

Suslyk, H. I., Kapustyns'ka, O. S., Hyryavenko, O. Ya. (2014). Rol' makro- ta mikroelementiv u patohenezi tsukrovoho diabetu 2-ho typu [The role of macro- and trace elements in the pathogenesis of type 2 diabetes]. Klinichna endokrynolohiya ta endokrynna khirurhiya, 2 (47), 19-24. https://doi.org/10.24026/1818-1384.2(47).2014.75438

Tkachenko, V. I., Vydyborets', N. V., \& Kovalenko, O. F. (2014). Analiz poshyrenosti ta zakhvoryuvanosti na tsukrovyy diabet i yoho uskladnennya sered naselennya Ukrayiny ta u Kyyivs'kiy oblasti za 2004-2013 r. [Analysis of the prevalence and incidence of diabetes mellitus and its complications among the population of Ukraine and Kyiv region for 2004-2013]. Zdobutky klinichnoyi i eksperymental'noyi medytsyny, 2, 177-82.

Tsytovs'kyy, M. N. (2017). Statystychnyy, klinichnyy ta morfolohichnyy aspekty vplyvu tsukrovoho diabetu na stan sertsevo-sudynnoyi systemy [Statistical, clinical and morphological aspects of the influence of diabetes on the condition of the cardiovascular system]. Naukovyy visnyk Uzhhorods'koho universytetu, seriya «Medytsyna», 1 (55), 168-177.

Venerucci, F. (2016). Histopathology kits: methods and applications. Bologna, Milan: Bio-Optica, 98.

Yigit M. V., Moore A., Medarova Z. (2012). Magnetic nanoparticles for cancer diagnosis and therapy. Pharm. Res, 29 (5), 1180-1188. https://doi.org/10.1007/s11095-012-0679-7

Zha, L. Y. et al. (2007). Effects of chromium nanoparticle dosage on growth, body composition, serum hormones and tissue chromium in Sprague-Dawley rats. J. Zhejiang. Univ. Sci. B, 8, 5, 323-330. https://doi.org/10.1631/jzus.2007.B0323 